40. Рішення Конституційного Суду України у справі за конституційним зверненням громадянина Голованя І.В. щодо офіційного тлумачення положень статті 59 Конституції України (справа про право на правову допомогу) від 30.09.2009 p. № 23-рп/2009. URL : https://zakon. rada. gov.ua/laws/show/v023p710-09 (дата звернення: 16.04.2019).

41. Рішення Конституційного Суду України у справі за конституційним зверненням Приватного малого підприємства - фірми «Максима» щодо офіційного тлумачення положень частини першої статті 59 Конституції України, частини першої статті 44 Господарського процесуального кодексу України (справа про відшкодування витрат на юридичні послуги у господарському судочинстві) від 11.07.2003 р. № 6-pп/2013. URL : https://zakon.rada.gov.ua/laws/show/v006p710-13 (дата звернення: 16.04.2019).

42. Про внесення змін до Господарського процесуального кодексу України, Цивільного процесуального кодексу України, Кодексу адміністративного судочинства України та інших законодавчих актів : Закон України від 03.10.2017 p. URL : https://zakon.rada.gov.ua/laws/show/2147-19 (дата звернення: 16.04.2019).

УДК 340.1

DOI https://doi.org/10.32844/2618-1258.2019.3-1.10

CMIPHOBA B.B.

\title{
ПРОЦЕС СТАНОВЛЕННЯ Й РОЗВИТКУ ІНСТИТУТУ ПРИСЯЖНИХ НА ТЕРИТОРІЇ УКРАЇНИ ПІСЛЯ СУДОВОЇ РЕФОРМИ 1864 РОКУ
}

Стаття присвячена аналізу розвитку інституту народного представництва під час здійснення правосуддя в цивільному судочинстві України після прийняття судових статутів 1864 року, висвітленню основних проблем, що виникали в процесі запровадження суду присяжних у радянській і незалежній Україні. Визначено, що активні реформи судової системи спонукають законодавця до вибору більш ефективної форми суду присяжних, про що свідчать законодавчі ініціативи в парламенті. Так, у Законопроекті «Про внесення змін до Кримінального процесуального кодексу України, Закону України «Про судоустрій і статус суддів» щодо удосконалення функціонування суду присяжних в Україні» від 21.08.2017 № 7022-1 пропонувалося запровадити в Україні класичну форму суду присяжних, яка б складалася з 12 основних присяжних і 12 додаткових. Передбачалося, що такий суд присяжних буде вирішувати «питання факту», а «питання права» будуть вирішуватися професійними суддями. 3'ясовано, що запровадження інституту присяжних на території України пов'язують із судовою реформою 1864 року. Аналізуючи цю реформу, можна дійти висновку, що суд присяжних був своєрідною шоковою терапією, запозичений із системи західного правосуддя. Але такий суд присяжних виявився занадто м'яким у винесенні обвинувальних рішень, що разом зі значною політизацією судових процесів призвело до обмеження кількості справ за участю присяжних, кризи інституту присяжних загалом i, як наслідок, повного скасування цього інституту в 1917 році. Зроблено висновок, що з моменту створення інституту народного представництва під час здійснення правосуддя характерним було його пристосування до політичних та економічних викликів. Брак самостійності й незалежності присяжних призвів до виключно декларативного існування цього інституту в цивільному судочинстві України. Досвід історичного розвитку інституту присяжних має бути врахований під час побудови нової моделі, яка, враховуючи реформи та виклики сьогодення, стане ефективним інструментом народного контролю і зниження корупційних ризиків під час прийняття судових рішень.

Ключові слова: присяжні, інститут присяжних, народні засідателі, суд присяжних.

СМІРНОВА В.В. - аспірантка кафедри цивільного права і процесу (Національна академія внутрішніх справ) 
The article is devoted to the analysis of the development of the institution of public representation in the administration of justice in civil proceedings of Ukraine after the adoption of the judicial charters in 1864, analysis of main problems that arose in the process of jury implementation in Soviet and independent Ukraine. It is determined that active reforms of the judicial system encourage the legislator to choose a more efficient form of jury trial, as evidenced by legislative initiatives in parliament. Thus, Bill No. 7022-1 "On Amendments to the Criminal Procedure Code of Ukraine, the Law of Ukraine" On Judicial System and Status of Judges "On Improving the Functioning of the Jury in Ukraine" of 21.08.2017 suggested the introduction of a classic jury trial in Ukraine consisted of 12 primary jurors and 12 additional. It was envisaged that such a jury would decide the "question of fact" and the "question of law" would be decided by professional judges. It has been found that the introduction of a jury institute in the territory of Ukraine is linked to the judicial reform of 1864. Analyzing this reform, we can conclude that the jury was a kind of shock therapy borrowed from the Western justice system. But such a jury found itself too lenient in its conviction, which, together with the considerable politicization of the trials, led to a restriction on the number of cases involving the jury, the crisis of the jury as a whole and, as a consequence, the complete abolition of this institution in 1917. It has been concluded that since the establishment of the People's Representation Institute during the administration of justice, it has been characterized by its adaptation to political and economic challenges. The lack of independence and independence of the jury led to the exclusively declarative existence of this institute in the civil proceedings of Ukraine. The experience of the historical development of the jury should be taken into account when building a new model that, given the reforms and challenges of today, will become an effective tool for popular control and reduction of corruption risks in judicial decision-making.

Key words: jury, jury institute, lay judges, jury trial.

Вступ. Розгляд питань, пов'язаних із запровадженням суду присяжних у сучасну правову систему України, є неможливим без дослідження та аналізу історії розвитку цього інституту. Судова реформа 1864 року запровадила на території сучасної України суд присяжних, що стало новим етапом розвитку судової системи загалом. У процесі свого історичного розвитку форми участі представників народу під час здійснення правосуддя змінювалися, від класичної моделі суду присяжних, запозиченої в США, до декларативної присутності народних засідателів як представників трудового колективу під час панування радянської влади. Інститут народних засідателів, як і судова гілка влади загалом, за часів радянської влади був позбавлений незалежності й був підзвітний державним структурам. Після здобуття незалежності України інститут народних засідателів був ліквідований як пострадянський елемент судової системи, але бажання будувати державу на демократичних засадах призвело до його відновлення в Конституції 1996 року. Сучасна модель суду присяжних потребує не вдосконалення, а створення абсолютно нової моделі, враховуючи виклики сьогодення, кризу судової влади та процес активних реформ. Аналіз історичного розвитку цього інституту дасть змогу визначити, яка з моделей була найбільш результативною з погляду виконання функцій, першочергово покладених на цей інститут.

Постановка завдання. Метою статті $є$ висвітлення основних періодів розвитку інституту представництва народу під час здійснення правосуддя після судової реформи 1864 року, аналіз основних проблем, які виникали в процесі впровадження цього інституту.

Історія виникнення й розвитку суду присяжних на території сучасної України досліджувалася в працях В. Городовенко, Т. Лисакова, Т. Нешик, Л. Сапейко, Тертишника, Т. Угненко, О. Шило, С. Штогуна, В. Щерби, О. Яновської та ін. Незважаючи на наявність окремих робіт, що стосуються історії розвитку суду присяжних на теренах України, відсутнє комплексне дослідження й періодизація історії формування та розвитку цього інституту після 1864 року.

Результати дослідження. Зачатки функціонування інституту присяжних спостерігаються в різних народів. Участь народу під час здійснення правосуддя була помічена ще з 6 століття до н.е. у Стародавній Греції, в Афінах, де розпочав функціонування своєрідний суд присяжних Геліея. Із самого початку становлення інституту присяжних основною ідеєю його функціонування було обмеження абсолютної влади та недопущення будь-якого королівського свавілля. Подальшого широкого розповсюдження інститут набув у ранньофеодальній Англії та Франції. Так, 
у Франції правосуддя здійснювалося шляхом залучення членів місцевої громади через інститут журату (лат. jurata - клятвені завірення), що оснований на звичаєвому праві, і рекогніторес (лат. recognitores - розпізнавати, розглядати), оснований на позитивному праві. В англійців необхідною передумовою для створення суду присяжних став фриборг, своєрідна адміністративно-територіальна одиниця, члени якої несли солідарну матеріальну відповідальність, основану на круговій поруці, як наслідок сусідської солідарності, що існувала в Англії ще в англосаксонський період. Отже, і в англійців, і у французів функціонував інститут, який можна назвати прототипом суду присяжних: судова влада здійснювалася в процесі плідної співпраці постійних і тимчасових суддів. Однак із часом у Франції народні судді були витіснені зі сфери судочинства професійними суддями остаточно, тоді як в Англії суд присяжних ніколи не переставав діяти. Тому більшість дослідників уважає, що суд присяжних - суто англійський інститут, який міг зародитися лише на теренах англійських правових звичаїв, оскільки ні у Франції, ні в будь-якій іншій державі не було передумови для зародження журі, а саме фриборгу, інституту суто англосаксонського [1, с. 37].

Незважаючи на ранні згадки про існування прототипу суду присяжних ще в Давній Греції, пізніше в ранньофеодальній Англії, Франції, виникнення цього інституту на пострадянському просторі відбулося тільки в ХІХ столітті.

Виникнення суду присяжних на український землях пов'язують із судовою реформою Олександра II в Російської імперії в 1864 році. Судові статути 1864 року фундаментально змінили судоустрій Російської імперії, поряд зі створенням адвокатури, нотаріату, мирових суддів був запроваджений суд присяжних, який був не результатом історичного розвитку судової системи, а фактично повністю новим для країни запозиченим інститутом. Уперше на територіях Російської імперії питання щодо винуватості чи невинуватості особи вирішували 12 присяжних. Кількість присяжних у Російській імперії, на думку істориків, запозичена з Англії, де історично лава присяжних складалася з 12 осіб.

Судова реформа передбачала відділення судових органів від адміністративних і виконавчих, проголошення принципів гласності, змагальності, рівності цивільних прав. Але реалізація цих законодавчих змін судової системи Російської імперії вимагала великої підготовчої роботи та значних фінансових ресурсів. Крім того, створення суду присяжних засідателів та інші демократичні засади судових статутів 1864 року викликали незадоволення в певних політичних сил імперії, які прагнули зберегти самодержавну владу царя, що в сукупності стало на заваді подальшому реформуванню державного устрою Російської імперії.

3 моменту першої спроби запровадити на теренах сучасної України інститут представництва народу під час здійснення правосуддя він зазнав суттєвих змін і пройшов низку етапів.

У науковій доктрині існує декілька підходів до періодизації розвитку суду присяжних на пострадянському просторі. А. Демичев та О. Ісаєнкова в роботах виокремлюють два етапи: дореволюційний (1864-1917) і сучасний (з 1993 року до сьогодні), кожен із який має власні періоди.

1. Період еволюційного розвитку (1864-1878). Судова реформа 1864 року встановила участь присяжних тільки в кримінальних справах, участь присяжних під час розгляду цивільних справ не передбачалася. Для потенційних присяжних було вставлено низку вимог: віковий, фізичний, майновий цензи та ценз осілості. Варто зауважити, що участь народу у здійсненні правосуддя як присяжних була громадським обов'язком, тому особа не могла відмовитися від участі в судових засіданнях як присяжного, крім випадків, передбачених законом.

Період із 20 листопада 1864 року по 9 травня 1878 року іменують періодом еволюційного розвитку інституту присяжних засідателів, оскільки положення Статутів щодо суду присяжних діяли в первісному вигляді практично без будь-яких серйозних змін, обмежень чи доповнень [2, с. 250].

2. Період кризи присяжних (1878-1889). У процесі розвитку суду присяжних були виявлені певні недоліки цього інституту. Головним недоліком уважається репресивність присяжних, яка була значно вища, ніж у професійних суддів. Злочини проти порядку управління засуджувалися в $64 \%$ випадках, що на 19,4\% нижче, ніж у випадках розгляду таких справ коронним судом. У справах проти громадського благоустрою присяжні засідателі засуджували тільки 47,2\% обвинувачених, тоді як коронні судді - 93\%, тобто різниця в репресії становила 46\% [3, с. 106].

3 огляду на значну репресивність присяжних і їхню незалежність від тиску владних структур, почалося поступове обмеження їхньої компетенції в 1878 році.

Указом від 9 травня 1878 року з підсудності присяжних вилучені справи про тероризм $і$ всі посадові злочини. Можна побачити, що вилучення саме цих категорій справ із компетенції суду присяжних свідчить про політизацію процесів і бажання носіїв владних повноваження захи- 
стити власні інтереси. При цьому явної критики зазнавали тільки присяжні, яких звинувачували в неповазі до суду та закону, а недоліки в роботі органів слідства й обвинувачення залишалися поза увагою.

Період із 1878 року по 1889 рік прийнято вважати кризою присяжних, викликаною трьома причинами: політичними, правовими та соціокультурними. Період кризи характеризується підвищенням вимог до присяжних (зміна соціального й освітнього складу присяжних), зменшенням їхньої компетенції, значною політизацією процесу функціонування цього інституту.

3. Період переоцінки інституту присяжних (1889-1917). Після завершення періоду кризи розпочинається процес переоцінки інституту присяжних і його початкова форма, прийнята ще в 1864 році, визнається такою, що не тільки виправдовує себе, а i, як зазначає А. Коні, є найкращою формою судочинства, яку лише можна було уявити, для вирішення більшої частини серйозних справ, особливо в тих випадках, коли тяжке обвинувачення пов'язане 3 доказами, що вимагають життєвої мудрості. У роботі «Вступительное и заключительное сообщение о суде присяжных и о суде с сословными представителями при руководстве совещаниями старших председателей и прокуроров судебных палат 29-31 декабря 1894 года» А. Коні писав, що за 30 років свого функціонування суд присяжних так сильно увійшов у руське життя, що, незважаючи на тимчасові та поодинокі випадки, які призводили до його критики, навряд чи можна всерйоз говорити про його скасування [4, с. 47-48].

4. Період нової кризи. Скасування суду присяжних. Після приходу до влади в 1917 році Тимчасового уряду суд присяжних зазнав нової кризи та, як наслідок, припинив своє існування на території Російської імперії після Жовтневої революції. 22 листопада (5 грудня) 1917 року Раднарком Декретом «Про суд» № 1 ухвалив: «Скасувати донині існуючі загальні судові встановлення, як-то: окружні суди, судові палати й Правлячий сенат з усіма департаментами ...». Відповідно, скасовувався й інститут присяжних засідателів, що діяв у цих судових установах [2, с. 251].

Отже, запровадження інституту присяжних на території України пов'язують із судовою реформою 1864 року. Аналізуючи цю реформу, можна дійти висновку, що суд присяжних був своєрідною шоковою терапією, який був запозичений із системи західного правосуддя. Але такий суд присяжних виявився занадто м'яким у винесенні обвинувальних рішень, що разом зі значною політизацією судових процесів призвело до обмеження кількості справ за участю присяжних, кризи інституту присяжних загалом i, як наслідок, повного скасування цього інституту в 1917 році.

Але, незважаючи на те що класичний суд присяжних ліквідований у 1917 році, залучення громадян до розгляду цивільних справ продовжувалося.

Особливо важливим правовим актом цього періоду був декрет Ради Народних Комісарів УРСР «Про суд» від 14 лютого 1919 року, яким ліквідовувалися «буржуазно-поміщицькі» суди (генеральний суд, судові палати, окружні суди, з'їзди мирових суддів, мирові суди, суди військові, морські, волосні, комерційні) та всі установи й організації, що були при них, і затверджувалося тимчасове Положення про народні суди й революційні трибунали УРСР, за яким в Україні, як і в РРФСР, створено дві самостійні судові системи: 1 - народні суди й ради народних суддів; 2 - революційні трибунали. Положення встановлювало, що народні суди діють у складі одного постійного судді і двох народних засідателів.

Отже, у 1919 році з'явилася інша форма представництва народу під час здійснення правосуддя, яка за своїм змістом суттєво відрізнялася від суду присяжних, запровадженого в 1864 році. Народні засідателі були представниками громадськості під час здійснення правосуддя й обиралися трудовим колективом строком на 3 роки. Під час розгляду справ народні засідателі наділялися всіма правами судді та приймали рішення колегіально. Проте говорити про незалежність останніх не варто, оскільки представники робітничих професій повністю підтримували й розділяли думку професійних суддів під час винесення рішень.

Радянський варіант участі громадян у здійсненні правосуддя дуже нагадує німецький суд шефенів. Маючи витоки в законодавстві Карла Великого VIII ст., суд шефенів у сучасному вигляді з'явився в Німеччині в середині XIX ст. і складався з коронного судді і двох засідателів шефенів. На відміну від суду присяжних, цей романо-германський аналог судового розгляду за участю представників народу утворює 3 професійним суддею єдиний склад. Нині в Німеччині цей інститут застосовується під час розгляду справ в адміністративних і трудових судах. В інших європейських державах діє подібний аналог. Отже, радянський інститут народних засідателів мав відповідні аналоги в інших європейських цивільних процесуальних системах.

Порядок розгляду справи із залученням народних засідателів неодноразово піддавався критиці. Деякі автори відзначали недосконалий характер обрання народних засідателів. На їхню 
думку, обрання народних засідателів на зборах окремих колективів порушувало принцип рівного виборчого права. Крім того, рішення народних засідателів прямо залежали від думки професійних суддів, авторитет яких був вищим за будь-яку думку представників народу. Більше того, сама судова система того часу перебуває в залежності від виконавчої влади й підзвітності їй [5, с. 164].

Тільки в статті 112 Конституції 1936 року вперше за майже 20 років із моменту становлення радянської влади визначалося, що судді незалежні й підпорядковуються тільки закону.

Проте це проголошення принципу незалежності суддівської гілки влади залишилося лише на папері, оскільки Народний комісаріат юстиції перевіряв шляхом проведення ревізій діяльність суддів і правильність застосування ними законів під час розгляду кримінальних і цивільних справ.

Після сплину майже півстоліття Конституцією СРСР 1977 року, а через рік і Конституцією УРСР 1978 року встановлювалося, що народні засідателі беруть участь у розгляді цивільних справ і кримінальних справ у суді першої інстанції та користуються всіма правами судді. Ця вимога відбилася у відповідному процесуальному законодавстві того часу.

У рамках судової реформи 1990-х років інститут народних засідателів скасовано. Незадоволеними роботою народних засідателів були передусім самі судді. Народні засідателі часто ухилялися від виконання своїх обов'язків, тому іноді до розгляду справ залучали й працівників суду. Безумовно, думки науковців і практиків того часу щодо доцільності існування в радянській системі інституту народних засідателів розділилися. Одні вважали це пережитком минулого, інші були переконані, що прагнення скасувати участь народу під час здійснення правосуддя $€$ політичним впливом на суддівську гілку влади.

Підсумовуючи процес становлення та розвитку інституту народного представництва за радянських часів, можна дійти висновку, що кожна з форм, які мав цей інститут у процесі свого історичного розвитку, зазнавала політичного впливу та позбавлялася тих першочергових рис незалежності й об'єктивності, які повинні б мати відповідно до мети свого функціонування.

На нашу думку, класична форма суду присяжних, запроваджена після 1864 року, могла стати ефективним інструментом контролю за здійсненням правосуддя, зменшення владного впливу на суддівські рішення. Проте участь народних засідателів у судових процесах як за часів радянської влади, так і за часів незалежної України залишалася конституційною формальністю.

Стаття 124 Конституції України 1996 року закріпила право народу на безпосередню участь під час здійснення правосуддя через народних засідателів і присяжних. Невизначеність щодо конкретної моделі народного представництва в суді й водночас бажання будувати нову державу виключно на демократичних засадах призвели до такого неоднозначного формулювання форм участі народу під час здійснення правосуддя в конституційній нормі.

Крім того, це конституційне право громадян залишалося декларативним до прийняття Цивільного процесуального кодексу України, в якому стаття 124 Конституції конкретизована, але конституційне право громадян на участь у здійсненні правосуддя обмежено чітко визначеною кількістю справ, до розгляду яких вони залучалися. Так, відповідно, у ч. 4 ст. 293 Цивільного процесуального кодексу України встановлюється перелік справ, до розгляду яких залучаються присяжні.

У 2016 році інститут народних засідателів ліквідовано шляхом прийняття Закону України «Про внесення змін до Конституції України (щодо правосуддя)». Пізніше, у 2017 році, з метою приведення норм Цивільного процесуального кодексу України у відповідність до Конституції України прийнято Закон України «Про внесення змін до Цивільного процесуального кодексу щодо розгляду справ за участю присяжних». Зміни щодо участі представників народу під час здійснення правосуддя в цивільних справах стосувалися тільки зміни термінології, форма участі останніх під час розгляду справ окремого провадження не змінилася.

Висновки. Пропонуємо виокремити такі етапи розвитку інституту народного представництва в цивільних справах із моменту здобуття Україною незалежності:

1.Період відновлення інституту народних засідателів (1996-2004). Закріплення в ст. 124 Конституції України права громадян на участь у здійсненні правосудді стало важливим кроком у становленні демократичних засад і забезпеченні права на справедливий суд.

2.Період упровадження інституту народних засідателів у цивільне судочинство (20042017). Цей період характеризується імплементацію конституційного права громадян на участь під час здійснення правосуддя в Цивільний процесуальний кодекс України. У частині 2 ст. 18 Цивільного процесуального кодексу України (в редакції від 06.11.2014) зазначається, що у випадках, установлених цим Кодексом, цивільні справи в судах першої інстанції розглядаються колегією в складі одного судді і двох народних засідателів, які під час здійснення правосуддя користуються 
всіма правами судді. Отже, декларативне право громадян на участь у здійсненні правосуддя реалізовано в цивільних процесуальних нормах після прийняття нового Цивільного процесуального кодексу України у 2004 році. Із цього моменту народних засідателів залучали до розгляду визначеної Кодексом категорії справ окремого провадження, у межах позовного провадження участь народних засідателів не передбачалася.

3.Період ліквідації інституту народних засідателів і впровадження суду присяжних (2017 рік - сьогодення). Законом України «Про внесення змін до Цивільного процесуального кодексу України щодо розгляду справ за участю присяжних» від 09.02.2017 інститут народних засідателів скасовано та запроваджено суд присяжних.

Нині недоцільно казати про відновлення класичного суду присяжних засідателів, оскільки зміни стосуються виключно термінології, сама ж форма участі громадян у здійсненні правосуддя залишилась незмінною. Але активні реформи судової системи спонукають законодавця до вибору більш ефективної форми суду присяжних, про що свідчать законодавчі ініціативи в парламенті. Так, у Законопроект «Про внесення змін до Кримінального процесуального кодексу України, Закону України «Про судоустрій і статус суддів» щодо удосконалення функціонування суду присяжних в Україні» від 21.08.2017 № 7022-1 пропонувалося запровадити в Україні класичну форму суду присяжних, яка б складалася з 12 основних присяжних і 12 додаткових. Передбачалося, що такий суд присяжних буде вирішувати «питання факту», а «питання права» будуть вирішуватися професійними суддями. Отже, як у науковому співтоваристві, так і в законодавчому полі залишаються актуальними питання щодо форми та підстав участі громадян у здійсненні правосуддя.

3 моменту створення інституту народного представництва під час здійснення правосуддя характерним було його пристосування до політичних та економічних викликів. Брак самостійності й незалежності присяжних призвів до виключно декларативного існування цього інституту в цивільному судочинстві України. Досвід історичного розвитку інституту присяжних має бути врахований під час побудови нової моделі, яка, враховуючи реформи та виклики сьогодення, стане ефективним інструментом народного контролю і зниження корупційних ризиків під час прийняття судових рішень.

\section{Список використаних джерел:}

1.Волоско І.Р. Суд присяжних в Україні: особливості формування та діяльності : дис. ... канд. юрид. наук : 12.00.09 / Міністерство освіти і науки України, Львівський національний університет ім. Івана Франка. Львів, 2014. С. 37.

2.Нешик T.С. Становлення суду присяжних в Україні наприкінці XIX - на початку XX століть. Науковий вісник Ужгородського наџіонального університету. 2014. Вип. 26. 249-253 с.

3.Демичев А.А. Суд присяжных в Российской Империи по судебным уставам 1864 г.: теория и практика. Університетські наукові записки. 2012. 106-107 с.

4.Кони А.Ф. Вступительное и заключительное сообщение о суде присяжных и о суде с сословными представителями при руководстве совещаниями старших председателей и прокуроров судебных палат 29-31 декабря 1894 года. Журнал Министерства юстииии. 1895. № 4. С. 47-48.

5.Гражданская процессуальная система России : монография. Москва, 2011. 164 с.

6.Конституція СРСР 1936 р. Глава IX.

7.Конституція України від 28.06.1996 / Верховна Рада України. URL: https://zakon.rada. gov.ua/laws/show/254к/96-вр.

8.Цивільний процесуальний кодекс України від 04.11.2018. URL: https://zakon.rada.gov.ua/ laws/show/1618-15.

9.Про внесення змін до Конституції України (щодо правосуддя) : Закон України від 02.06.2016. URL: https://zakon.rada.gov.ua/laws/show/1401-19.

10. Про внесення змін до Цивільного процесуального кодексу щодо розгляду справ за участю присяжних : Закон України від 09.02.2017. URL: https://zakon.rada.gov.ua/laws/show/1847-19. 